\title{
THE INFLUENCE OF TOP-DOWN STRATEGY (TDS) ON STUDENTS' READING COMPREHENSION
}

\author{
Dwi Darsa Prasetyo, Ummi Khaerati Syam, Saiful, \\ Ismail Sangkala \\ English Education Department, Faculty of Teacher Training and Education \\ Makassar Muhammadiyah University \\ dwidarsa27@gmail.com
}

\begin{abstract}
This research aimed to find out the influence of Top-Down Strategy (TDS) on students reading comprehension that focus on level of literal and interpretative of comprehension. The researcher applied pre-experimental method with one group pre-test and post-test. The sample of this research was class XI MIA 2 of SMA Negeri 10 GOWA which consisted of 30 students. The sample was taken by using purposive sampling method. The result of the research were the mean score of pretest in Literal (main Idea) score of pretest was 58.6 and post-test was 86.56. In sequence of detail the score of pretest was 56.4 and post-test was 92.6 with $t$-test value Literal is greater than t-table (13.26 > 2.45). Mean score of intrepretative in pretest was 63.63 and post-test was 82 with the t-test value is greater that $t$-table $(8.34>2.45)$. The result of calculating $t$-test of the indicators in the students'-test (Literal and Interpretative) was greater than t-table $21.60>2.45$. it means that there was significance different between before and after giving the treatment. Based on explanation above we concluded that using Top-Down Strategy is influence and improve students reading comprehension especially in literal and interpretative levels.
\end{abstract}

Keywords: Top Down Strategy (TDS), Narrative text, Reading Comprehension, Teaching Reading.

\section{INTRODUCTION}

Language is social aspect of human life, a fundamental part of human in society and a form of behavior. One of the functions of language is as an instrument of communication. Beside to maintain relationship with others, it is also considered a symbol of social identify and an emblem of social group membership and solidarity. Without using language, it is hard to imagine how people can cooperate with one another. Communication can be analyzed in term of the person involved and the social context, as well as the language use. As an international language, English is very important and has many interrelationship with various aspects of life owned by human being.

In Indonesia, English considered as the first foreign language and taught formally from junior high school up to the university level. Considering to the 
important of English, the teacher must give more attention to the teaching and learning process in order to the students are able to communicate using the target language in oral and written forms accurately and fluently. In learning English, there are four skills that must be mastered students are: writing, listening, reading, and speaking.

Reading is an activity analyze, and interpret conducted by the reader to get a message to be delivered by the author in writing media. Reading is the ability to anticipate the meaning of the lines in the text. The activity read not only the mechanical activity, but rather an intention to capture the activity of groups of words that carry meaning. In addition, reading is a skill development, ranging from skills to understand the words, sentences, paragraphs in reading through a critical and evaluative understand the overall content of reading.

However, based on the observation and interview with English teachers at SMA Negeri 10 Gowa, there are some problems that he found in teaching reading in the classroom. The first, the students' ability to understand the reading is very low. Students have difficulties in reading and finding the meaning of the reading. The result in students' achievement in the reading skill becomes decreased and even worse. The second, the students are difficult in answer the reading test. They don't understand the meaning and the purposes of the text.

Therefore, the teacher needs teaching strategy which that can cover all the problems and the teachers are demanded to create some strategies or activities which can explore the students' reading skill. One of the activities that can be used to teach reading is Top-Down Strategy.

Top-Down Theory is known as the psycholinguistic model in reading and theory developed by Goodman (2015). The process of reading this model begins with the hypothesis and predictions by using a stimulus in the form of writing in the text. The essence of the Top-Down theory model is that the reader begins the process of understanding the text from a higher level.

Reffering to consider above, the researcher is interested in conducting a researcher under the title "The Influence of Top-Down Strategy (TDS) On 
Students Reading Comprehension at The Second Grade of SMA Negeri 10 Gowa."

\section{METHOD}

Related with the background above, the researcher formulated the following researcher question:

a. How the Top-Down Strategy influence the Literal students reading comprehension?

b. How the Top-Down Strategy influence the interpretative students reading comprehension?

Based on the research problem above, the objective of the research is formulated as follows:

a. To know whether or not the use of Top-Down Strategy influence the Literal students' reading comprehension.

b. To know whether or not the use of Top-Down Strategy influence the interpretative students' reading comprehension.

The result of this research was expected to be able to overcome problems and facilitate students in learning reading comprehension. Is also expected to be useful for English teachers in teaching and also useful for the author himself. This research was limited by the influential of Top-Down Strategy towards the students' reading Comprehension. This research focus on the students' reading comprehension at the level of literal (Main Idea and Sequence Detail) and interpretative (Making Conclusion) comprehension at the second grade of SMA Negeri 10 Gowa Kabupaten Gowa.

The population of this research is the second grade students of SMA Negeri 10 Gowa in the 2016/2017 academic year. The number of population 120 students consist of four classes; each class consisted of 30 students. The writer took only one class as the sample and respondents of this research. The number of the sample is 30 students were chosen (II IPA 2 ). The researcher applied purposive sampling technique. 


\section{Research Instrument}

a. Interview

The researcher conducted interviews with english teacher, this interview aims to obtain data about learning english especially in learning reading comprehension. The type of this interview used by the researcher is the Semi-Structured Interview.

b. Reading Test

Reading comprehension test were employed as an instrument to collected data. Pretest given before treatment and posttest were given after the researcher given the treatment. The test consist of essay test to assess the students' literal and the students' interpretative comprehension.

c. Students' Daily Assessment

Each meeting, the researcher provides daily assessment to the students. Daily assessment was given in essay test from Narrative text. Giving daily assessment aims to see the progress of students every week during the treatment. Daily assestment also aims to provide practice to students to more easily do post test, facilitate finding main idea, sequence of detail and making conclusion in literal and interpretative reading comprehension.

\section{Technique of Collecting Data}

a. Pretest

Before doing treatment, the researcher was given a pre-test. Students in the class joining the test. The researcher distributed to identify the students' prior knowledge in reading comprehension. The pre-test were given in the first meeting. The researcher was given narrative text as reading material and the students answer the question of the narrative text.

b. Posttest

After doing treatment, the writer post-test for the experimental class. It last for $2 \times 45$ minutes. The post-test were conducted to find out the students' achievement and their progress after giving the treatment about the 
use top down strategy in teaching reading comprehension. The content of the pretest same as the post test.

\section{Technique of Data Analysis}

To analysis the data, the writer employed the rubric and formula as follows;

Table 1. Rubric for the Main Idea

\begin{tabular}{|c|l|c|}
\hline No & \multicolumn{1}{|c|}{ Criteria } & \multicolumn{1}{|c|}{ Score } \\
\hline 1 & $\begin{array}{l}\text { The answer includes a clear generalization that state or implies the } \\
\text { main idea. }\end{array}$ & 4 \\
\hline 2 & The answer states or implies the main idea & 3 \\
\hline 3 & Indicator inaccurate or incomplete understanding of the main idea. & 2 \\
\hline 4 & The answer includes minimal or no understanding of the main idea. & 1 \\
\hline
\end{tabular}

(Harmer in Hariyati, 2013:27)

Table 2. Rubric for the Sequence of Details

\begin{tabular}{|c|l|c|c|c|c|c|}
\hline \multirow{2}{*}{ No } & \multicolumn{1}{|c|}{ Criteria } & \multicolumn{5}{|c|}{ Score } \\
\cline { 3 - 7 } & \multicolumn{1}{|c|}{$\mathbf{1}$} & $\mathbf{2}$ & $\mathbf{3}$ & $\mathbf{4}$ & $\mathbf{5}$ \\
\hline 1 & $\begin{array}{l}\text { The students answer full and correct } \\
\text { answer related to the content of } \\
\text { reading text. }\end{array}$ & 20 & 20 & 20 & 20 & 20 \\
\hline 2 & $\begin{array}{l}\text { The students give short answer and } \\
\text { the answer is in completed. }\end{array}$ & 15 & 15 & 15 & 15 & 15 \\
\hline 3 & $\begin{array}{l}\text { The students answer is incorrect and } \\
\text { the explanation is poor. }\end{array}$ & 5 & 5 & 5 & 5 & 5 \\
\hline 4 & There is no answer & 0 & 0 & 0 & 0 & 0 \\
\hline
\end{tabular}

(Hecklemen in Hariyati, 2013:27)

Table 3. Rubric for the Rubric for Conclusion

\begin{tabular}{|c|c|c|}
\hline No & Criteria & Score \\
\hline 1 & $\begin{array}{l}\text { The conclusion reflects resource readings in a development of idea it } \\
\text { is excellent. }\end{array}$ & 4 \\
\hline 2 & $\begin{array}{l}\text { The conclusion reflects resource readings in a development of idea it } \\
\text { good. }\end{array}$ & 3 \\
\hline 3 & reflects resource readings in development of idea it is poor & 2 \\
\hline 4 & $\begin{array}{l}\text { Conclusion does not reflect any reading of resources in development } \\
\text { idea. }\end{array}$ & 1 \\
\hline
\end{tabular}

(Kissner in Hariyati, 2013:28) 
1. Calculating the Students' Score

The students' score of reading comprehension calculated through the formula:

$$
\text { Scoring }=\frac{\text { Total Correct Answer }}{\text { maximum score }}=\mathrm{x} 100
$$

(Depdikbud in sari, 2010:32)

2. Calculating the mean score of the students' achievement by using the following formula:

$$
\vec{X}=\frac{\sum X}{N}
$$

Where: $\overrightarrow{\mathrm{X}}=$ Mean Score $\Sigma \mathrm{X}=$ the total row score $\quad \mathrm{N}=$ Total Sample

(Gay in Hariyati, 2013:29

After collecting the data of the students, the researcher classified the score of students. There are seven classification which are used as follow:

Table 4. Classification the Score of Students

\begin{tabular}{|c|c|c|}
\hline No & Classification & Score \\
\hline 1 & Excellent & $96-100$ \\
\hline 2 & Very Good & $86-95$ \\
\hline 3 & Good & $76-85$ \\
\hline 4 & Fairly Good & $66-75$ \\
\hline 5 & Fair & $56-65$ \\
\hline 6 & Poor & $46-55$ \\
\hline 7 & Very Poor & $0-45$ \\
\hline
\end{tabular}

(Depdikbud, 2004:27)

3. Finding of significant different between the pretest and postest by calculating the value of the test :

$$
\mathrm{t}=\frac{\bar{D}}{\sqrt{\frac{\sum D 2 \frac{\left(\sum D\right)^{2}}{N}}{N(N-1)}}}
$$

$$
\text { Natation: } \quad \begin{array}{ll}
\mathrm{t} & =\text { Test of significant differences } \\
\bar{D} & =\text { The mean score of total deviation }
\end{array}
$$




$$
\begin{array}{ll}
\sum D & =\text { The sum of total score difference } \\
\sum D 2 & =\text { The square of the sum score for difference } \\
\mathrm{N} & =\text { Total number }
\end{array}
$$

(Gay in Hariyati, 2013:31)

\section{FINDINGS}

1. The Improvement of the Students' Reading Comprehension Using Top-Down Strategy (TDS) In Literal and Interpretive

Students' reading comprehension using Top-Down Strategy (TDS) have different in pre-test and post-test. In pre-test students still less understand about literal and interpretive but after applied Top-Down Strategy (TDS) the students more understand about literal and interpretive reading comprehension, it can be

\begin{tabular}{|c|c|c|c|c|}
\hline \multirow{2}{*}{ No } & \multirow{2}{*}{ Indicator } & \multicolumn{2}{|c|}{ Mean score } & \multirow{2}{*}{$\begin{array}{c}\begin{array}{c}\text { Students' Improvement } \\
(\%)\end{array} \\
\text { Pre-test to Post-test }\end{array}$} \\
\hline & & Pre-Test & Post-Test & \\
\hline 1 & Literal & 57.5 & 89.58 & $55 \%$ \\
\hline 2 & Interpretive & 63.63 & 82 & $28 \%$ \\
\hline & $\sum \mathrm{X}$ & 121.13 & 171.58 & $41 \%$ \\
\hline & $\mathrm{X}$ & 60.56 & 85.79 & $41 \%$ \\
\hline
\end{tabular}
seen clearly in the following table:

Table 5. The Mean Score of Students' Reading Comprehension

The table above shows the mean score of students' achievement in reading comprehension both of literal and interpretive. Based on the table, it indicated that the improvement of the students' reading comprehension by using Top-Down Strategy (TDS) was successful. The students' mean score in pre-test was 60.56 score and the students' mean score in post-test was 85.79 score. Thus, the improvement of the students' reading comprehension between pre-test to post-test was $41 \%$.

2. The Percentage of the Students' Achievement in Literal and Interpretive Reading Comprehension Using Top-Down Strategy (TDS)

a. Literal Reading Comprehension 
The following table and chart show the percentage of students' achievement in reading comprehension in term of literal before and after application of TopDown Strategy (TDS).

Table 6. The Percentage of Students' Reading Achievement in Literal

\begin{tabular}{|c|c|c|c|c|c|c|}
\hline \multirow{2}{*}{ No. } & \multirow{2}{*}{ Classification } & \multirow{2}{*}{ Score } & \multicolumn{4}{|c|}{ Literal } \\
\cline { 3 - 7 } & & & \multirow{2}{*}{ Pre-test } & \multicolumn{2}{|c|}{ Post-test } \\
\cline { 3 - 7 } & & Freq & \% & freq & \% \\
\hline 1 & Excellent & $96-100$ & 0 & 0 & 8 & $26.66 \%$ \\
\hline 2 & Very Good & $86-95$ & 0 & 0 & 3 & $10 \%$ \\
\hline 3 & Good & $76-85$ & 2 & $6.66 \%$ & 18 & $60 \%$ \\
\hline 4 & Fairly Good & $66-75$ & 8 & $26.66 \%$ & 1 & $3.33 \%$ \\
\hline 5 & Fair & $56-65$ & 8 & $26.66 \%$ & 0 & 0 \\
\hline 6 & Poor & $46-55$ & 5 & $16.66 \%$ & 0 & 0 \\
\hline 7 & Very Poor & $0-45$ & 17 & $23.33 \%$ & 0 & 0 \\
\hline \multicolumn{2}{|c|}{ Total } & & $\mathbf{3 0}$ & $\mathbf{1 0 0 \%}$ & $\mathbf{3 0}$ & $\mathbf{1 0 0 \%}$ \\
\hline
\end{tabular}

The table above shows the result of students' reading comprehension in term of literal in pre-test and post-test. In pre-test, 2 students (6.66\%) got good, 8 students (26.66\%) classified into Fairly Good, 8 students (26.66\%) got fair, 5 students (16.66\%) classified into Poor, and nobody got Excellent and Very Good pre-test. In post-test, there were 8 students (26.66\%) classified into Excellent score, 3 students (10\%) classified into Good score, 18 students (60\%) got Good score 1 student (3.33\%) classified into Fairly Good score and nobody classified into Fair, Poor and Very Poor.

\section{b. Interpretive Reading Comprehension}

The following table and chart show the percentage of students' achievement in reading comprehension in term of interpretive before and after application of Top-Down Strategy (TDS). 
Table 7. The Percentage of Students' Reading Achievement in Interpretive

\begin{tabular}{|c|c|c|c|c|c|c|}
\hline \multirow{3}{*}{ No. } & \multirow{3}{*}{ Classification } & \multirow{3}{*}{ Score } & \multicolumn{4}{|c|}{ Interpretive } \\
\hline & & & \multicolumn{2}{|c|}{ Pre-test } & \multicolumn{2}{|c|}{ Post-test } \\
\hline & & & Freq & $\%$ & Freq & $\%$ \\
\hline 1 & Excellent & $96-100$ & 0 & 0 & 0 & 0 \\
\hline 2 & Very Good & $86-95$ & 0 & 0 & 3 & $10 \%$ \\
\hline 3 & Good & $76-85$ & 2 & $6.66 \%$ & 23 & $76.66 \%$ \\
\hline 4 & Fairly Good & $66-75$ & 15 & $50 \%$ & 4 & $13.33 \%$ \\
\hline 5 & Fair & $56-65$ & 4 & $13.33 \%$ & 0 & 0 \\
\hline 6 & Poor & $46-55$ & 6 & $20 \%$ & 0 & 0 \\
\hline 7 & Very Poor & $0-45$ & 3 & $10 \%$ & 0 & 0 \\
\hline & Total & & 30 & $100 \%$ & 30 & $100 \%$ \\
\hline
\end{tabular}

The table above shows the result of students' reading comprehension in term of Interpretive in pre-test and post-test. In pre-test, 6 students (20\%) got Poor, 3 students (10\%) classified into Very Poor, 4 students (13.33\%) got Fair score, 15 students (50\%) got Fairly Good score and nobody got Excellent, Very Good, and Good. In post-test, there were 4 students (13.33\%) classified into Fairly Good, 23 students (76.66\%) classified into Good score, 3 students (10\%) got very good score and nobody classified into Excellent, Fair, Poor and Very Poor.

Table 8. Comparison of T-test and T-table Score of the Students Reading Comprehension

\begin{tabular}{|l|l|l|l|}
\hline \multicolumn{1}{|c|}{ Variables } & t-test & t-table & Description \\
\hline Literal reading comprehension & 13.26 & 2.45 & Significance \\
\hline $\begin{array}{l}\text { Interpretive } \\
\text { reading Comprehension }\end{array}$ & 8.34 & 2.45 & Significance \\
\hline \multicolumn{1}{|c|}{$\mathrm{X}$} & 21.60 & 2.45 & \\
\hline
\end{tabular}

Table 8 Showed that the value of the $t$ - test is higher than the value of $t-$ table. The t-test value of literal reading was greater than $t$-table $(13.26>2.45)$ and t-test value interpretive reading are greater than t-table $(8.34>2.45)$. The result of calculating t-test of the indicators in the students' $t$-test in literal and interpretive was greater than t-table (21.60>2.45. It is said that the null hypothesis (Ho) was rejected and the alternative hypothesis (H1) was accepted. It means that there is a 
significance difference between, the result of the students' literal and interpretive reading comprehension in reading through Top-Down Strategy (TDS) after treatment.

\section{DISCUSSION}

The data collected in pre-test and post-test in case of the students literal and interpretative comprehension was show significant different. It was supported by the rate percentage and score frequently in the result of the students' before and after applying Top-Down Strategy (TDS) in teaching reading comprehension. The explanation below:

\section{a. The students' reading comprehension before applying Top-Down Strategy in teaching reading.}

Based on the pre-test data, the score frequency and rate percentage of the students' before using Top-Down Strategy applied, the students' reading comprehension particular in narrative text was no one of the students' got excellent and very good. The classification of the students' before applying TopDown Strategy were good, fairly good, fair, and poor. There were 1 (3.33\%) classify as good, 21 students' (70\%) got fairly good, 3 students' (10\%) got fair, and the poor score was gotten 5 (16.67).

\section{b. The students' reading comprehension after using Top-Down Strategy in teaching reading.}

Base on the post-test data, the score frequency and rate percentage of the students' after applying Top-Down Strategy (TDS), the students' reading comprehension particular in narrative text was one of the students' got excellent. They were categorized in excellent, very good, good, and fairly good classification. None of the students got score fair, poor, and very poor in posttest. There were $1(3.33 \%)$ of 30 students who got excellent score, $11(36.67 \%)$ of the students' got very good score, $16(53.33 \%)$ of the students got good score and 2 $(6.67 \%)$ of the students got fairly good score. Thus, the researcher concluded that the use of Top-Down Strategy (TDS) influence and improved the students' reading comprehension especially in literal and interpretative levels. 


\section{c. The Difference of the students' reading comprehension before and after applying Top-Down Strategy (TDS).}

Under the previous consideration, there was a significance difference between the students' reading comprehension before and after applying TopDown Strategy (TDS). The mean score of the students' reading comprehension before applying Top-Down Strategy (TDS) was 67.83 and then mean score of the students' reading comprehension after applying Top-Down Strategy (TDS) was 87.36. It shows that the mean score of the students' reading comprehension after applying Top-Down Strategy (TDS) was higher than the mean score of the students' reading comprehension before and after applying Top-Down Strategy (TDS).

The value of the t-test was higher than t-table value (9.38-2.45). Base on the result of t-test calculation, the researcher found that there was a significant between the result of the students' reading comprehension before and after applying Top-Down Strategy (TDS).

\section{CONCLUSION}

Based on the findings and discussion in the privious sections, the researcher concludes that:

1. In literal of students' comprehension of Main Idea of the story indicated that the students'mean score of pretest was 58.6 and it classified as fair and in post test was 86.56 and it classified as very good. So, the improvement of students' achievement in Main Idea was $47 \%$.

2. In literal level of students' comprehension of Sequence Detail indicated that the students'mean score of pretest was 56.4 and it classified as fair and in post test was 92.6 and it classified as very good. So, the improvement of students' achievement in interpretative was $64 \%$.

3. In interpretative of students' comprehension in Making conclusion of the story indicated that the students'mean score of pretest was 63.63 and it classified as fair and in post test was 82 and it classified as good. So, the improvement of students' achievement in interpretative was $28 \%$. 


\section{REFERENCES}

Abraham, Paul.2010. Article of skilled Reading: Top-Down, Buttom-up. (Online), https://sites.google.com/skilled-reading-top-down-buttom-up.

Carrol, Lewis.2015. Developmental reading 1. (Online), (https://https.slideshare.n et/minejsca/top-down-aproaches. 2015

Depdikbud (2004).Petunjuk pelaksanaan Proses Belajar Mengajar dan petunjuk pelaksanaan System Penelitian. Jakarta: Dictionary of Education New York.

Dr. Janette M. Hughes. 2007. Teaching language and Literary, K-6, Reading process, (Faculty.Voit.ca/hughes/Readingprocess.html.

Goodman, 2015. Study of A Comperative Study of Buttom-up and Top-down Approaches Reading Comprehension-islamic University of Malang, Indonesia. (Online), www.academia.edu/25303130/A-comperative-studyof-Buttom-up-and-top-down-approaches-in-maximing-readingcomprehension.

Hariyati.2013. The Application of Graphic Organizer Method in Improving Reading comprehension at The first Year Students' of SMK Handayani Sungguminasa Gowa (A Class Action Research). FKIP Unismuh 